\title{
PREDETERMINING VALUE ANALYSIS OF THE PREHOSPITAL PHASE PROCEDURES IN TRAUMA VICTIMS SURVIVAL
}

Marisa Aparecida Amaro Malvestio ${ }^{1}$ Regina Marcia Cardoso de Sousa ${ }^{2}$

Malvestio MAA, Sousa RMC. Predetermining value analysis of the prehospital phase procedures in trauma victims survival. Rev Latino-am Enfermagem 2008 maio-junho; 16(3):432-8.

The aim of this study was to analyze the determining value of the procedures carried out during prehospital care in the survival time of traffic accident victims. Data of 175 victims with Revised Trauma Score $£ 11$, cared for and transported by advanced life support to tertiary referral hospitals, were submitted to Kaplan-Meier Survival Analysis and to Cox proportional hazards model. Four procedure groups associated with survival were identified: basic circulatory; advanced respiratory; volume replaced and medication. Until hospital discharge, the victims who underwent orotracheal intubation and chest compressions showed 3.6 and 6.4 times higher death hazards, respectively. The need for definitive airway and cardiopulmonary resuscitation in the prehospital phase was predetermining with higher death hazard. The less than 1000ml intravenous fluid replacement was the only predetermining factor with protective power against death hazard.

DESCRIPTORS: prehospitalcare; accidents; traffic; proportional hazards model

\section{ANÁLISIS DEL VALOR PREDETERMINANTE DE LOS PROCEDIMIENTOS DE LA FASE PREHOSPITALARIA EN LA SOBREVIVENCIA DE LAS VÍCTIMAS DE TRAUMA}

La propuesta de este estudio fue analizar el valor determinante de los procedimientos realizados durante la atención prehospitalaria en el tiempo de sobrevivencia de víctimas de accidentes de tránsito. Datos de 175 víctimas con Revised Trauma Score $\leq 11$, atendidas y transportadas por el soporte avanzado a la vida a hospitales terciarios, fueron sometidos al análisis de sobrevivencia de Kaplan Méier y al análisis de Riesgos Proporcionales de Cox. Se identificaron 4 grupos de procedimientos asociados a la sobrevivencia: circulatorios básicos; respiratorios avanzados; volumen repuesto y medicamentos. Hasta el alta hospitalaria, las víctimas sometidas a la intubación orotraqueal y compresiones toráxicas presentaron 3,6 y 6,4 veces mayor riesgo de muerte, respectivamente. La necesidad de mantener la vía aérea definitiva permeable y hacer reanimación cardiorrespiratoria en la fase prehospitalaria fue predeterminante de un mayor riesgo de muerte. La reposición de volumen inferior a $1000 \mathrm{ml}$ fue el único factor predeterminante con fuerza protectora para el riesgo de muerte.

DESCRIPTORES: assistencia prehospitalaria; accidentes de tránsito; modelos de riesgos proporcionales

\section{ANÁLISE DO VALOR PREDETERMINANTE DOS PROCEDIMENTOS DA FASE PRÉ- HOSPITALAR NA SOBREVIVÊNCIA DAS VÍTIMAS DE TRAUMA}

A proposta deste estudo foi analisar o valor predeterminante dos procedimentos realizados, durante o atendimento pré-hospitalar no tempo de sobrevivência de vítimas de acidentes de trânsito. Dados de 175 vítimas com Revised Trauma Score $\leq 11$, atendidas e transportadas pelo suporte avançado à vida a hospitais terciários, foram submetidas à Análise de Sobrevivência de Kaplan Méier e à Análise de Riscos Proporcionais de Cox. Identificou-se 4 grupos de procedimentos associados à sobrevivência: circulatórios básicos; respiratórios avançados; volume reposto e medicamentos. Até a alta hospitalar, as vítimas, submetidas à entubação orotraqueal e compressões torácicas, apresentaram 3,6 e 6,4 vezes maior risco para o óbito, respectivamente. A necessidade de realização de via aérea definitiva e de reanimação cardiorrespiratória na fase pré-hospitalar foi predeterminante de maior risco para o óbito. A reposição de volume inferior a $1000 \mathrm{ml}$ foi o único fator predeterminante com força protetora para o risco de óbito.

DESCRITORES: assistência pré-hospitalar; acidentes de trânsito; modelos de riscos proporcionais

${ }^{1}$ Ph.D. in Nursing, Coordinator, SAMU 192 Education Center, São Paulo, Brazil, Faculty, e-mail: marisaaph@itelefonica.com.br; ${ }^{2}$ Faculty, Free Lecturer, University of São Paulo School of Nursing, Brazil, e-mail: vian@usp.br 


\section{INTRODUCTION}

Many researchers have attempted to determine the factors related to trauma victims' survival. It is an international research trend, searching evidence of performed interventions' efficacy, as well as safe prognosis indicators for this victims group $^{(1-2)}$.

The surveyed factors involve victims' characteristics, trauma type and its mechanisms and the circumstances of the delivered care from the prehospital phase through hospital setting, including the procedures performed in both phases ${ }^{(1-3)}$. However, there is difficulty in statistically demonstrating the association between these factors and survival, due to the great number of variables that interfere in the results, along with the difficulty in extracting the impact of one or a specific group ${ }^{(1,3-6)}$.

In the prehospital phase, this difficulty has been even more evident, mainly when the study objective is to verify the influence of advanced life support (ALS) measures, which require invasive procedures. These difficulties are inherent to the retrospective nature of data collection, victim evaluation difficulties in the accident scene, lack of standardization and differences in care models offered by different countries, which make it difficult to compare mortality studies ${ }^{(1-2)}$.

In trauma ALS research, there is a trend to focus its influence on closed traumas ${ }^{(1,3,5,7)}$, the performance of some procedures, such as intubation and volume replacement ${ }^{(5)}$, and accidents in rural areas, where the distance between the trauma scene and the hospital is further ${ }^{(5)}$.

These restrictions and the difficulty in pointing out the statistical association with the survival results maintains the controversy about EMS, mainly between rapidly removing the victim of the trauma scene to the hospital (scoop and run) or delivering care in the accident scene (scene stabilization) and, with this, delay the arrival to definitive care ${ }^{(1,3,8-9)}$.

Being aware of the predetermining value of the EMS phase procedures can help in the decision to perform such procedures and staff training.

This study aims to analyze the predetermining value of basic and advanced support procedures, performed during the EMS phase, on traffic accident victims' survival, taking into account time intervals until hospital discharge.

\section{METHOD}

This is a longitudinal retrospective study, using pre- and intra-hospital data of traffic accident victims reported in the city of São Paulo/Brazil, between April 1999 and March 2003. The primary data sources were the "Prehospital Care Form", the victim hospital records and, when appointed, the necropsy report. The data were accessed after approval by the Ethics and Research Committee of USP Nursing School and the São Paulo Municipal Health Secretary, besides proper formal authorizations from people in charge in the different institutions involved. Taking into account the retrospective nature of the research in the records, authorization of the sample subjects through the free and informed consent term was not necessary.

All victims were 12-65 years old, showed Revised Trauma Score (RTS) $\leq 11$ in the accident scene and were cared for and transported by an ALS team of the municipal EMS, to a public tertiary care center. Restrictions on the victims' inclusion in the sample sought to guarantee similar conditions and survival expectancy, as recommended by other studies ${ }^{(1-2)}$.

The procedures, analyzed in a single or combined way, included:

Basic respiratory support: oxygen therapy, Guedel canula and aspiration;

Immobilizations: cervical collar, stretcher and limb immobilization;

Basic circulatory support: external chest compression and compression bandage;

Advanced Respiratory Support: orotracheal intubation (OTI), percutaneous transtracheal ventilation (PTV), puncture and/or thoracic drainage;

Advanced circulatory support: peripheral or central venous access;

Volume and type of solution for volume replacement: $>$ or $\leq$ than $1000 \mathrm{ml}$ solution and lactated Ringer's solution and/or physiological solution;

Medication: psychotropics, adrenaline (atropine, lidocain), glycosis and others.

To distinguish between premature and late deaths, the dependent variable used in the survival analysis was the time elapsed from the accident to the outcome (death, discharge or transference), in different time intervals. The considered intervals were: up to 6 , 12,24 and 48 hours and up to 7 days and up to hospital discharge. In order to determine time, the date, hour and hospital discharge status were collected from the tertiary referral hospital straight from the records.

The Kaplan-Meier Survival Analysis (KMSA) was used to select the procedures associated with survival ( $p \leq 0.05$ ). In this analysis, death was considered as an event and living patients were discharged or transferred. Each time interval was considered as censorship. The procedures that showed association with survival in the KMSA were subject to Cox proportional hazards model (CPHM), which established the relative hazard of subject death in these procedures, and those who did not require interventions (baseline category) ${ }^{(10)}$. 
In CPHM, values higher than 1 for hazard estimate of a variable means that the group exposed to it shows higher death risks than the non-exposed group and therefore, the prognosis is worse. Values between 0 and 1 show the category protective power or variable, demonstrating a lower death risk ${ }^{(10)}$.

Cox's hazard coefficients of the categories with statistically significant associations are presented as graphs, which allows for the analysis of behavior and category impact over time. The database and statistical analysis were organized in SPSS 10.0. software.

\section{RESULTS}

This study sample was made up of 175 traffic accident victims; most of them in the age group of 2039 years $(61.1 \%)$ and males $(86.9 \%)$. The mean age was 31.9 years $(S D=11.3$; mean $=30)$. Overall, $45.1 \%$ of the victims were pedestrians, $30.9 \%$ were motorcyclists and $18.9 \%$ were driving automobiles. The mean RTS in the scene was 8.8 (SD $=3.2$; mean $=$ 10 ), in the Glasgow Coma Scale (GCS) 9.2 (SD = 4.2; mean $=9$ ) and the mean Injury Severity Score (ISS) reached $19.4(S D=14.1$, mean $=17, \min 1, \max 57)$.

Immobilizations and oxygen therapy were the most common support procedures (Table 1 ). It was necessary for $9.2 \%$ of the victims the cardiopulmonary resuscitation (CPR) procedure, along with chest compression.

Table 1 - Distribution (no. and \%) of victims, according to basic support procedures in the prehospital phase. São Paulo, 1999-2003

\begin{tabular}{|c|c|c|}
\hline Procedures & $\mathbf{N}$ & $\%$ \\
\hline \multicolumn{3}{|l|}{ Respiratory } \\
\hline Oxygen therapy & 96 & 54.9 \\
\hline Oxygen therapy+Guedel Canula+Aspiration & 61 & 34.9 \\
\hline Oxygen therapy + Guedel Canula & 11 & 6.2 \\
\hline Subtotal & 168 & 96.0 \\
\hline Not performed & 6 & 3.4 \\
\hline No information & 1 & 0.6 \\
\hline Total & 175 & 100 \\
\hline \multicolumn{3}{|l|}{ Circulatory } \\
\hline Compression Bandage & 106 & 60.5 \\
\hline $\begin{array}{l}\text { Chest Compression (with or without Compression } \\
\text { Bandage) }\end{array}$ & 16 & 9.2 \\
\hline Subtotal & 122 & 69.7 \\
\hline Not performed & 52 & 29.7 \\
\hline No information & 1 & 0.6 \\
\hline Total & 175 & 100 \\
\hline \multicolumn{3}{|l|}{ Immobilization } \\
\hline Cervical Collar and Stretcher & 88 & 50.3 \\
\hline Cervical Collar + Stretcher + Limb Immobilization & 78 & 44.6 \\
\hline Cervical Collar + Dorsal Immobilizing Vest+ Stretcher & 7 & 4.0 \\
\hline Subtotal & 173 & 98.9 \\
\hline No information & 2 & 1.1 \\
\hline Total & 175 & 100 \\
\hline
\end{tabular}

Among the advanced procedures (Table 2) OTI and peripheral venous puncture stand out. Regarding the used volume, in $63.4 \%$ of the victims, $\leq 1000 \mathrm{ml}$ values were chosen, with the Ringer lactate solution, the most used in volume replacement. The use of adrenaline occurred predominantly during the CPR procedures.

Table 2 - Distribution ( $\mathrm{n}^{\circ}$ and \%) of victims, according to advanced support procedures in the prehospital phase. São Paulo. 1999-2003

\begin{tabular}{|c|c|c|}
\hline Procedures & $\mathbf{N}$ & $\%$ \\
\hline \multicolumn{3}{|l|}{ Advanced respiratory } \\
\hline OTI & 55 & 31.4 \\
\hline PTV & 5 & 2.9 \\
\hline Thoracic Puncture & 3 & 1.7 \\
\hline OTI + Thoracic Puncture & 3 & 1.7 \\
\hline OTI + Thoracic Puncture + Thoracic Drainage & 1 & 0.6 \\
\hline Subtotal Performed & 67 & 38.3 \\
\hline Not performed & 107 & 61.1 \\
\hline No information & 1 & 0.6 \\
\hline Total & 175 & 100 \\
\hline \multicolumn{3}{|l|}{ Advanced circulatory } \\
\hline Peripheral Venous Puncture & 158 & 90.3 \\
\hline Phlebotomy & 2 & 1.1 \\
\hline Venous Puncture + Defibrillation & 3 & 1.7 \\
\hline Subtotal Performed & 163 & 93.1 \\
\hline Not performed & 11 & 6.3 \\
\hline No information & 1 & 0.6 \\
\hline Total & 175 & 100 \\
\hline \multicolumn{3}{|l|}{ Volume and replaced solution } \\
\hline Lactated Ringer's Solution $\mathbf{0} 1000 \mathrm{ml}$ & 91 & 52.0 \\
\hline Lactated Ringer's Solution > 1000ml & 32 & 18.4 \\
\hline Physiological Solution $\mathbf{0 1 0 0 0 m l}$ & 17 & 9.7 \\
\hline Physiological Solution > 1000ml & 6 & 3.4 \\
\hline $\begin{array}{l}\text { Lactated Ringer's Solution + Physiological Solution > } \\
1000 \mathrm{ml}\end{array}$ & 6 & 3.4 \\
\hline $\begin{array}{l}\text { Lactated Ringer's Solution + Physiological Solution 0 } \\
\text { 1000ml }\end{array}$ & 3 & 1.7 \\
\hline Glucose Solution & 2 & 1.1 \\
\hline Subtotal Performed & 157 & 89.7 \\
\hline Not performed & 11 & 6.3 \\
\hline No information & 7 & 4.0 \\
\hline Total & 175 & 100 \\
\hline \multicolumn{3}{|l|}{ Medication } \\
\hline Psychotropics, sedatives or myorelaxative drugs & 28 & 16.0 \\
\hline Adrenaline with or without Atropine and Lidocain & 11 & 6.3 \\
\hline Others & 11 & 6.3 \\
\hline Hypertonic Glycosis & 8 & 4.5 \\
\hline Subtotal Performed & 58 & 33.1 \\
\hline Not performed & 116 & 66.3 \\
\hline No information & 1 & 0.6 \\
\hline Total & 175 & 100 \\
\hline
\end{tabular}

Taking into account the exit status and the time elapsed until death, (Table 3), 63 deaths are observed, 32 (50.8\%) of which happened up to 6 hours after the trauma. 
Table 3 - Distribution of victims ( $\mathrm{n}^{\circ}$ and \%), according to exit status and interval up to death after trauma event. São Paulo 1999-2003

\begin{tabular}{lcc}
\hline \multicolumn{1}{c}{ Exit Status } & N & $\%$ \\
\hline Death up to $6 \mathrm{~h}$ & 32 & 18.3 \\
Death from $6 \mathrm{~h}$ to $<12 \mathrm{~h}$ & 5 & 2.9 \\
Death from $12 \mathrm{~h}$ to $<24 \mathrm{~h}$ & 4 & 2.3 \\
Death from $24 \mathrm{~h}$ to $<48 \mathrm{~h}$ & 3 & 1.7 \\
Death from $48 \mathrm{~h}$ to $\mathbf{0} 7$ days & 6 & 3.4 \\
Death in Period higher than 7 days & 13 & 7.4 \\
Subtotal Deaths & 63 & 36.0 \\
Hospital discharge & 108 & 61.7 \\
No information $\left(^{*}\right)$ & 4 & 2.3 \\
Total & 175 & 100 \\
\hline
\end{tabular}

(*) transferred patients

In the KMSA applied to 7 different procedure groups in the prehospital phase, 4 were identified, with statistically significant association with survival, in all evaluated time intervals, namely basic circulatory $(p<0.001)$; advanced respiratory $(p<0.001)$; replaced volume $(p<0.05)$ and administered medication $(p<0.001)$. Basic respiratory and advanced circulatory procedures were associated with survival exclusively in the 6 hour -12 hour intervals $(p \leq 0.02)$ and up to 7 days $(p<0.05)$, respectively. Immobilization procedures were not statistically associated.

The CPHM, applied to procedural groups in the KMSA selected procedures, revealed the following categories with significant association with survival in all time intervals: chest compressions, venous access, volume replacement with less than $1000 \mathrm{ml}$ volumes, CPR medication administration and all categories related to advanced respiratory procedures. The administration of sedatives and pain killers was associated only between $48 \mathrm{~h}$ and 7 days.

Figure 1 shows the risk coefficient's behavior for death in the advanced respiratory procedure categories.

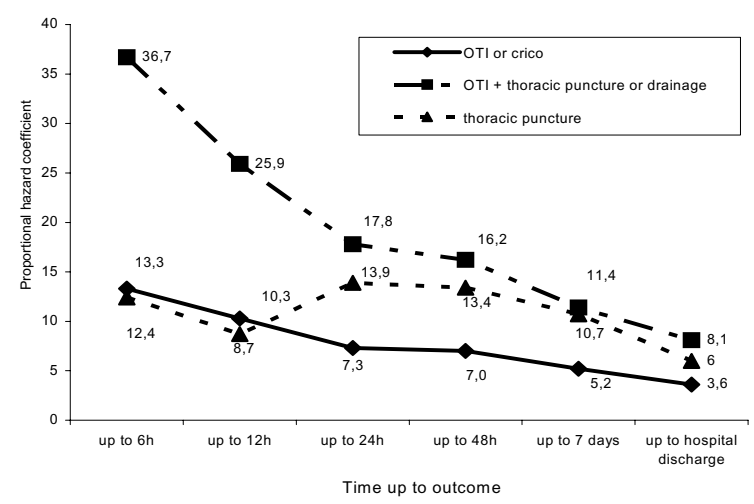

Figure 1 - Cox proportional hazard coefficients for the advanced respiratory procedure categories, according to studied time intervals. São Paulo. 19992003
Of the 67 victims who received OTI or PTV, 23 survived. In the first $6 \mathrm{~h}$, OTI or PTV application resulted in a 13.3 times higher death risk $(p<0.001)$ in the victims who received this procedure when compared with those who did not. In the group who needed OTI or PTV $(n=60)$, all victims had ISS $\geq 25$, and 24 of them died within $6 \mathrm{~h}$. From $6 \mathrm{~h}$ onwards after trauma, there is a decline in deaths of victims who need these procedures.

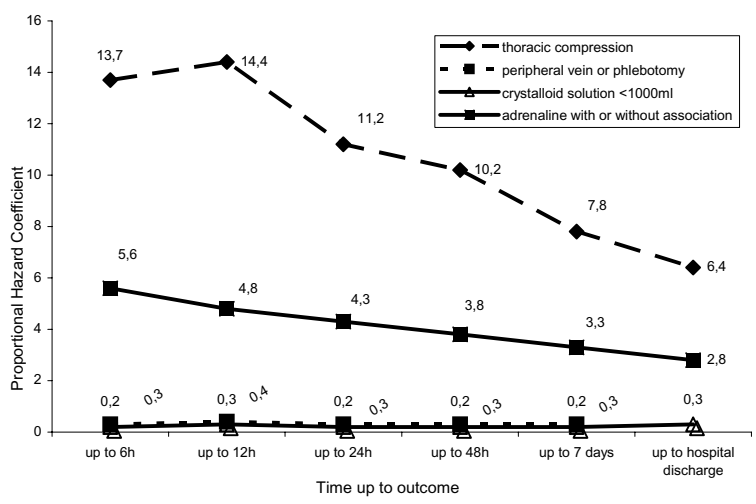

Figure 2 - Cox proportional hazards for basic and advanced circulatory procedure categories, according to the studied time intervals. São Paulo. 1999-2003

The behavior of basic and advanced circulatory procedure hazard coefficients is shown in Figure 2. Also, with a downward trend as time goes by, chest compression increased 6.4 times the death risk until hospital discharge. Among the 16 victims who received $C P R$ in the EMS phase, there were 2 survivors.

The need for $\leq 1000 \mathrm{ml}$ volume replacement produced hazard coefficients lower than 1 in all evaluated time intervals. Similar behavior was observed with the "peripheral vein or phlebotomy" category, which showed association in most intervals. Among the 111 victims who received $\leq 1000 \mathrm{ml}$ volumes, 74 survived.

The administration of sedative drugs or pain killers was a significant prognosis factor only in the "up to $48 \mathrm{~h}$ " and "up to 7 days" intervals. The observed coefficients indicate a lower death risk in the presence of this procedure.

The need of glycosis administration with volumes over $1000 \mathrm{ml}$, compression bandage and defibrillation did not show statistical evidences of association with death. The basic respiratory support 
procedure did not confirm the CPHM statistical association in any of the intervals.

\section{DISCUSSION}

In the present study, the procedures that stood out as determining for survival were related to advanced respiratory support, RCP and volume replacement.

In EMS, applying advanced respiratory support procedures, especially OTI, is defended by several researchers, because premature oxygen restoration and ventilation may decrease post-trauma complications and, therefore, improve survival outcomes $^{(1,3,9)}$. However, in the present study, the death risk of victims subject to this procedure was high.

Concerning theoretical advantages of OTI use, there are difficulties in obtaining evidence in favor of the procedure, due to the impossibility to perform studies with control groups and mainly because victims who need OTI already show higher death risk as they need invasive respiratory assistance to maintain this vital function ${ }^{(7,11)}$. Various studies have already addressed the relation among gravity, need for OTI and death ${ }^{(1,4,12-14)}$.

However, there are no evidences showing that this procedure should not be performed during EMS. On the contrary, studies ${ }^{(12-13)}$ that compared mortality in victims subject to OTI in accident scenes and in hospital showed that, for the first group, there were higher survival rates, leading the authors to assess lower survival for the second group because of delay in performing the procedure, which caused even worse prognoses. These outcomes, when associated with high death risk caused by OTI in the present sample, lead to the need to analyze the hypothesis that OTI is not a risk factor, but that the need for the procedure is a risk indicator.

The need for procedures inherent to CPR also showed high death risk. However, of the 16 victims who needed CPR, 2 survived (12.5\%).

$\mathrm{CPR}$ in trauma patients during the prehospital phase has already been considered by some authors as an example of inappropriate consumption of medical and hospital resources due to its bad prognosis ${ }^{(15-16)}$. However, recent studies on blunt trauma victims who received ALS, have confirmed the existence of a higher survival rate after CPR (ranging from $3.5 \%$ to $9.3 \%$ of survivors) ${ }^{(15-16)}$. Such results, along with those shown, which also demonstrate a good survival rate (if CPR is performed), have an important clinical impact. The EMS advances should revise their operational protocols and clearly determine the indicative parameters of initial CPR maneuvers at the trauma scene. EMS and ALS teams, when dealing with closed trauma with CPR, should evaluate the possibility of investing all available resources while still in the accident scene and during transport, with a view to increasing the victim's chances.

The realization of venous puncture during EMS is a priority procedure, especially in CPR or shock cases $^{(4,11)}$. If analyzed exclusively, its realization does not show clinical meaning. However, its objective is to allow for medication administration and mainly the volume replacement and, only when analyzed in this context does this procedure gain meaning. In the present study, all these procedures were associated with survival.

Volume replacement is controversial ${ }^{(1-2,4,7)}$ : not performing the replacement can lead to hypoxemia and uncompensated shock ${ }^{(1)}$; on the other hand, performing replacement can normalize systolic blood pressure (SBP) and improve perfusion. Even so, as a consequence of pressure elevation, hydraulic acceleration of hemorrhage and mechanical displacement of blood clots may occur, triggering another bleeding ${ }^{(1)}$. Yet, there is the risk of clotting factors dilution in great fluid replacement, which may increase the bleeding duration and worsen shock ${ }^{(1)}$.

International studies defend replacement, but with lower volumes until arrival to definitive care ${ }^{(1,7)}$. In this proposal, the procedure does not increase AP excessively. However, it prevents microcirculation disorders and anaerobic metabolism provoked by shock. In the present sample results, the administration of less than $1000 \mathrm{ml}$ volumes was the only category that showed risk coefficients with protective behavior in all periods, which may be an important factor to maximize surviving probability and may be associated with lower shock occurrence in the victim group that received lower volumes ${ }^{(1,7)}$. 
In general, the variables related to prehospital phase procedures, when subject to Cox models, showed there is a declining trend in the risk coefficients until hospital discharge. Among the reasons for such decline are the low number of events (deaths), which were accumulated after $6 \mathrm{~h}$ and the likelihood that CPR measures' impact is limited to a time interval.

For the interventions that showed coefficients with protective power, the behavior trend is linear, indicating that the benefit or protective power attained may influence the outcomes for a longer period.

Concerning the results observed in this study, it is important to point out that the number of basic and advanced support procedures was high in the victim group. Even considering that several of them were not associated with survival, the need for these procedures can be related to premature alterations of the circulatory, respiratory and neurological functions, detected in victims still in the EMS phase and corroborated by the presence of RTS $\leq 11$ in the accident scene. The lack of procedure benefit evidences does not imply restrictions to its realization. Procedures performed in most of the victims, such as immobilization and oxygen therapy, did not show significant association, probably due to sample homogeneity.

If the victim needs premature intervention and it is performed early, it is a sign of benefit obtained through EMS. From this standpoint, the analysis of EMS impact should be done from the perspective of the need for the procedure, aiming for prevention or correction of physiological irregularities from the trauma.

\section{REFERENCES}

1. Hodgetts TJ, Smith J. Essential role of prehospital care in the optimal outcome from major trauma. Emerg Med 2000; 12:103-11

2. Macfarlane C, Benn CA. Evaluation of emergency medical systems : a classification to assist in determination of indicators. Emerg Med J 2003; 20(2):188-91.

3. Pepe PE. Controversies in prehospital management of major trauma. Emerg Med 2000; 12:180-9.

4. Kaweski SM, Sise MJ, Virgilio RW. The effect of prehospital fluids on survival in trauma patients. J Trauma 1990; 30(10):1215-9.

5. Spaite DW, Criss EA, Valenzuela TD, Meislin HW. Prehospital advanced life support for major trauma: critical need for clinical trials. Ann Emerg Med 1998; 32(4):480-9.
EMS teams should take into account that traffic accident victims with $\mathrm{RTS} \leq 11$ who need invasive respiratory procedures or CPR have a high premature death risk and that, therefore, fast interventions and sending to the tertiary referral hospital are key items to provide the victims with intra-hospital benefits.

For this victim group, it is imperative to establish an intervention protocol fast enough for each necessity-specific group, so as to affect victims' survival without taking unnecessary time. Making fast interventions requires trained teams to recognize the need for realization, besides performing them within the minimum time possible.

\section{CONCLUSION}

The analysis of the predetermining values of the procedures performed during prehospital care in survival time allows for the following conclusions: Advanced respiratory procedures, external chest compressions and the use of medication related to CPR stood out because of their significant association with higher death risk in all time intervals. On the other hand, volume replacement with lower than $1000 \mathrm{ml}$ volumes was a protective factor in all evaluated periods.

In specific periods, venous access through peripheral vein or phlebotomy and the use of sedative drugs or pain killers was a protective factor, decreasing death hazard.

6. Eckestein M, Chan L, Scheiner A, Palmer R. Effect of Prehospital Advanced Life Support on Outcomes of Major Trauma Patients. J Trauma 2000; 48(4):643-8.

7. Regel G, Stalp M, Lehmann U, Seekamp A. Pre-hospital care, importance of early intervention on outcome. Acta Anaesthesiol Scand 1997; 110:71-6.

8. Cayten CG, Murphy JG, Stahal WM. Basic life support versus advanced life support for injured patients with an injury severity score of 10 or more. J Trauma 1993; 35(3):460-7.

9. Liberman M, Mulder D, Sampalis J. Advanced or basic life support for trauma: meta-analysis and critical review of the literature. J Trauma 2000; 49(4):584-99.

10. Walters SJ. What is a Cox model ?. Aventis [serial online] 2003 May; 1(10). [Cited May 23, 2004]. Available from:www.evidence-based-medicene.co.uk.data.

11. Murray JA, Demetriades D, Berne TV, Stratton SJ, Cryer HG, Bongard $F$, et al. Prehospital intubation in patients with severe head injury. J Trauma 2000; 49(6):1065-70. 
12. Arbabi S, Jurkovich GJ, Wahl WL, Franklin GA, Hemmila MR, Taheri PA, et al. A comparison of prehospital and hospital data in trauma patients. J Trauma 2004; 56(5):1029-32.

13. Winchell RJ, Hoyt D B. Endotracheal intubation in the field improves survival in patients with severe head injury. Arch Surg 1997; 132:592-7.

14. Baxt WG, Moody P. The impact of advanced prehospital emergency care on the mortality of severely brain injured patients. J Trauma 1987; 27(4):365-9.

15. Di Bartholomeu S, Sanson G, Nardi G, Michelutto V, Scian F. HEMS vs Ground BLS care in traumatic cardiac arrest. Prehosp Emerg Care 2005; 9(1): 79-84.

16. Pickens JJ, Copass MK, Bulger EM. Trauma Patients receiving CPR:predictors of survival. J Trauma 2005; 58(5):951-8. 